\title{
The Influence of Asset Structure, Capital Structure, Risk Management and Good Corporate Governance on Financial Performance and Value of The Firm through Earnings and Free Cash Flow As An Intervening Variable in Banking Companies Listed in Indonesia Stock Exchange
}

\author{
Catur F. Ukhriyawati ${ }^{1}$, Tri Ratnawati ${ }^{2} \&$ Slamet Riyadi $^{2}$ \\ ${ }^{1}$ Universitas Riau Kepulauan Batam, Indonesia \\ ${ }^{2}$ Universitas 17 Agustus 1945 Surabaya, Indonesia \\ Correspondence: Priyono, Post Graduate Management Program, Universitas Bina Darma, Palembang, Indonesia. \\ E-mail: priyono.unu_sidoarjo@yahoo.com
}

Received: May 2, 2017

doi:10.5539/ijbm.v12n8p249

\author{
Accepted: June 27, 2017 \\ Online Published: July 18, 2017 \\ URL: https://doi.org/10.5539/ijbm.v12n8p249
}

\begin{abstract}
Banking companies that have gone public has the goal of increasing prosperity of the owners or shareholders by increasing the value of the company. The value of the company is very important because of the high value of the company which will be followed by a high prosperity shareholders. This study aimed to analyze the influence of asset structure, capital structure, risk management and good corporate governance on financial performance and value of the firm through earnings and free cash flow as an intervening variable in banking companies listed in Indonesia Stock Exchange. Data analysis techniques use Partial Least Square (PLS) and from data processing and hypothesis testing, produced 13 accepted hypothesis and 8 hypothesis is rejected. The results of this study were (1) asset structure influence positive and significantly to earnings, (2) capital structure influence negative and significantly to earnings, (3) risk management influence positive and no significantly to earnings, (4) Good Corporate Governance influence positive and significantly to earnings, (5) asset structure influence positive and significantly to free cash flow, (6) capital structure influence positive and no significantly to free cash flow, (7) risk management influence negative and no significantly to free cash flow, (8) Good Corporate Governance influence positive and no significantly to free cash flow, (9) asset structure influence negative and no significantly to financial performance, (10) capital structure influence negative and significantly to financial performance, (11) risk management influence positive and no significantly to financial performance, (12) Good Corporate Governance influence positive and significantly to financial performance, (13) asset structure influence positive and significantly to value of the firm, (14) capital structure influence positive and no significantly to value of the firm, (15) risk management influence negative and significantly to value of the firm, (16 ) Good Corporate Governance influence positive and significantly to value of the firm, (17) earnings influence positive and significantly to financial performance, (18) free cash flow influence positive and significantly to financial performance, (19) earnings influence positive and significantly to value of the firm, (20) free cash flow influence positive and no significantly to value of the firm and (21) financial performance influence positive and significantly to value of the firm.
\end{abstract}

Keywords: asset structure, capital structure, risk management, good corporate governance, earnings, free cash flow, financial performance and value of the firm

\section{Introduction}

Banking is a strategic tool in the development of economy. Bank an important financial institutions that affect the economy both in micro and macro. Its function as financial intermediary between the parties that the excess funds with the parties who need funds or deficit. In running his business as a financial institution that sells trust and services, each bank trying as much as possible attract new customers, increase their funds and also increase lending and their services.

Companies that have good performance will increase the value of the company (Suharli, 2006). Based on the results of the study by Fang et al. (2008), the performance of a good company will demonstrate the value of the 
company is high, so it can be an attraction for investors to invest.

Free cash flow is the source of conflict for the stakeholders and the shareholders, as the difference between the interests of both parties. The shareholders want the rest of the funds were distributed to promote prosperity through dividend payments, while the management wants to free cash flow used for investment projects profitable in the future. Brigham and Houston (2010) defines free cash flow as cash flow available for distribution to all investors after the companies to invest in fixed assets, new products and working capital required to maintain the continuity of the company's operations.

According Munawir (2007) mentions that the earnings is demonstrating the company's ability to generate profits for a certain period. Earnings a company can be measured by the success of the company and the company's ability to use assets productively, thus the earnings of a company can be determined by comparing the profits obtained in one with total assets or total capital of the company.

Assets are all the resources and property owned by the company for use in the activities of the company. Companies generally have two types of assets are current assets and fixed assets. The second element of these assets will form the structure of assets. Asset structure of an enterprise will appear in the left side of the balance sheet. Asset structure is also called asset structure or the structure of wealth. Asset structure or the structure of Equalization or comparative wealth is both in terms of absolute and in relative terms between the current assets to fixed assets (Riyanto, 2008).

Capital structure theory explains that the financial policy in determining the company's capital structure (mix between debt and equity) aimed at optimizing value of the firm. Capital structure of a company is a combination of debt and equity (external sources) which maximizes stock price enterprises. At the given moment, the company's management set a target capital structure, which may be an optimal structure, even though the target may be changed from time to time. Bank capital is funds invested by the owners in order to establishing businesses intended to finance the bank's business activities in addition to meet the regulations set by the monetary authority (Taswan, 2010).

Banks are required to apply risk management effectively. Risk management is a set of procedures and methodologies used to identify, measure, monitor and control risks arising from business activities banks. Risk management is one important element in conducting banking business for the growing world of banking as well as the increasing complexity of these banks. This has resulted in an increased level of risk faced by banks (Pandia, 2012).

In order to improve the Bank's performance, protect the interests of stakeholders, and improve compliance with legislation and regulations, and ethical values generally accepted in the banking industry, the Bank shall conduct its operations guided by the principles of Good Corporate Governance (GCG). Black et al (2006) in Malik (2012) company that does good corporate governance can provide a signal that companies will behave well so that could affect the company's stock price.

\section{Theory}

\subsection{Assets Structure}

According to Weston and Brigham within Husnan (2005) assets structure are: Balance, or the ratio between fixed assets and total assets. Meanwhile, according Syamsudin (2007) the structure of assets is the determination of how much the allocation of funds for each component of assets, both in current assets and in fixed assets.

Assets structure by Titman and Wessels (1988) in Kesuma (2009) is the wealth or economic resources owned by the company which is expected to provide benefits in the future that consists of fixed assets, intangible assets, current assets and assets smoothly.

\subsection{Capital Structure}

According Sartono (2009) stated that the capital structure is balancing the number of short-term debt that is permanent, long-term debt, preferred stock and common stock.

Meanwhile, according to Besley and Brigham (2008), the capital structure is measured by comparing the total debt by total assets, which reflects the size of the fund through debt either for current or long term debt on the asset as a whole.

\subsection{Risk Management}

Banks are required to apply risk management effectively. Risk management is a set of procedures and methodologies used to identify, measure, monitor and control risks arising from business activities bank. Risk 
management is one important element in conducting banking business for the growing world of banking as well as the increasing complexity of these banks. This has resulted in an increased level of risk faced by banks (Pandia, 2012).

\subsection{Good Corporate Governance}

Good corporate governance is a system of corporate governance which contains a set of rules that govern the relationship between shareholders, management (manager) of the company, the creditors, governments, employees and holders of other internal and external interests in relation to the rights and obligations or in other words, a system that regulates and controls the company, with the aim to increase the value added to stakeholders. If the implementation of good corporate governance can work effectively and efficiently, the whole process of the activity of the company will run well, so that matters pertaining to the company's performance both its financial performance and non-financials will also improve (Brown and Caylor 2004 ).

The Indonesian Institute for Corporate Governance (IIGC) (2001) defines Corporate Governance as a process and structure applied in running the company, with the main goal of improving shareholder value in the long term, with due regard to stakeholders interest others.

\subsection{Earnings}

According to Pandia (2012). Earnings are a tool to measure the bank's ability to generate profits by comparing earnings with assets or capital for a certain period. Earnings also shows how the company's management of capital account capital owners submitted to him, it was pointed out by how much the dividend.

Munawir (2007) earnings or profitability is demonstrating the company's ability to generate profits for a certain period. Earnings of a company is measured by the success of the company and the ability to use assets productively, thus the earnings of a company can be determined by comparing the income earned in a period by the number of assets or the amount of capital the company.

Brigham and Houston (2010) is a profitability ratio that shows a group of the ratio of the combined effects of liquidity, asset management, and debt to operating results.

\subsection{Free Cash Flow}

Brigham and Houston (2010) defines free cash flow as cash flow available for distribution to all investors after the companies to invest in fixed assets, new products and working capital required to maintain the continuity of the company's operations.

Jensen (1986) defines free cash flow (free cash flow) as cash remaining after all projects which generate net present value (NPV) is done. Companies with excess free cash flow will have a better performance compared to other companies because they can take advantage of various opportunities which may not be obtained by other companies.

Kieso, Weygandt and Warfield (2007) defines free cash flow as the amount of discretionary cash flow of a company that can be used for additional investments, pay off debt, buy back its own shares (treasury stock), or increase the company's liquidity.

Subramanyam and Wild (2009) describes the free cash flow is cash from operating activities minus net capital changes and changes in working capital. Free cash flow in the company shows an additional effect on the investment or disinvestment in operating assets. Sightings free cash flow in the company shows free cash to be used as repayment of indebtedness or return to shareholders.

\subsection{Financial Performance}

According to the Indonesian Institute of Accountants (IAI) (2007), the financial performance is the company's ability to manage and control their resources.

The financial performance is the description of the achievement of the company's success can be interpreted as the results achieved on the various activities that has been done. Can explained that financial performance is an analysis done to see the extent to which a company has implemented using operational rules of good financial and right (Fahmi, 2014).

According Sawir (2009) which states that financial performance is a condition that reflects a company's financial situation based on your goals, standards and criteria set.

\subsection{Value of the Firm}

The purpose of the establishment of the company is to maximize the company's value (value of firm), especially 
for companies that have gone public is reflected in its share price. To achieve its objectives, the company must carry out its activities effectively and efficiently in order to generate the maximum profit that would be expected also to maximize the wealth of investors.

According to Fama (1978), the value of the company can be seen from the share price. The stock price is formed on the demand and supply of investors, so that the stock price can be used as a proxy for the value of the company.

According to Jensen (2001), to maximize corporate value not only equity values are considered, but the sources of finance such as debt and Its preferred shares. Husnan and Pudjiastuti (2004) argues that the value of the company is willing to share price paid by the prospective buyer if the company is sold.

\subsection{Conceptual Framework}

Overall conceptual framework model in the picture below illustrates the influence of inter variable. These variables is the influence of Asset Structure, Capital Structure, Risk Management and Good Corporate Governance on Financial Performance and Value of the Firm Through Earnings And Free Cash Flow as an intervening variable.

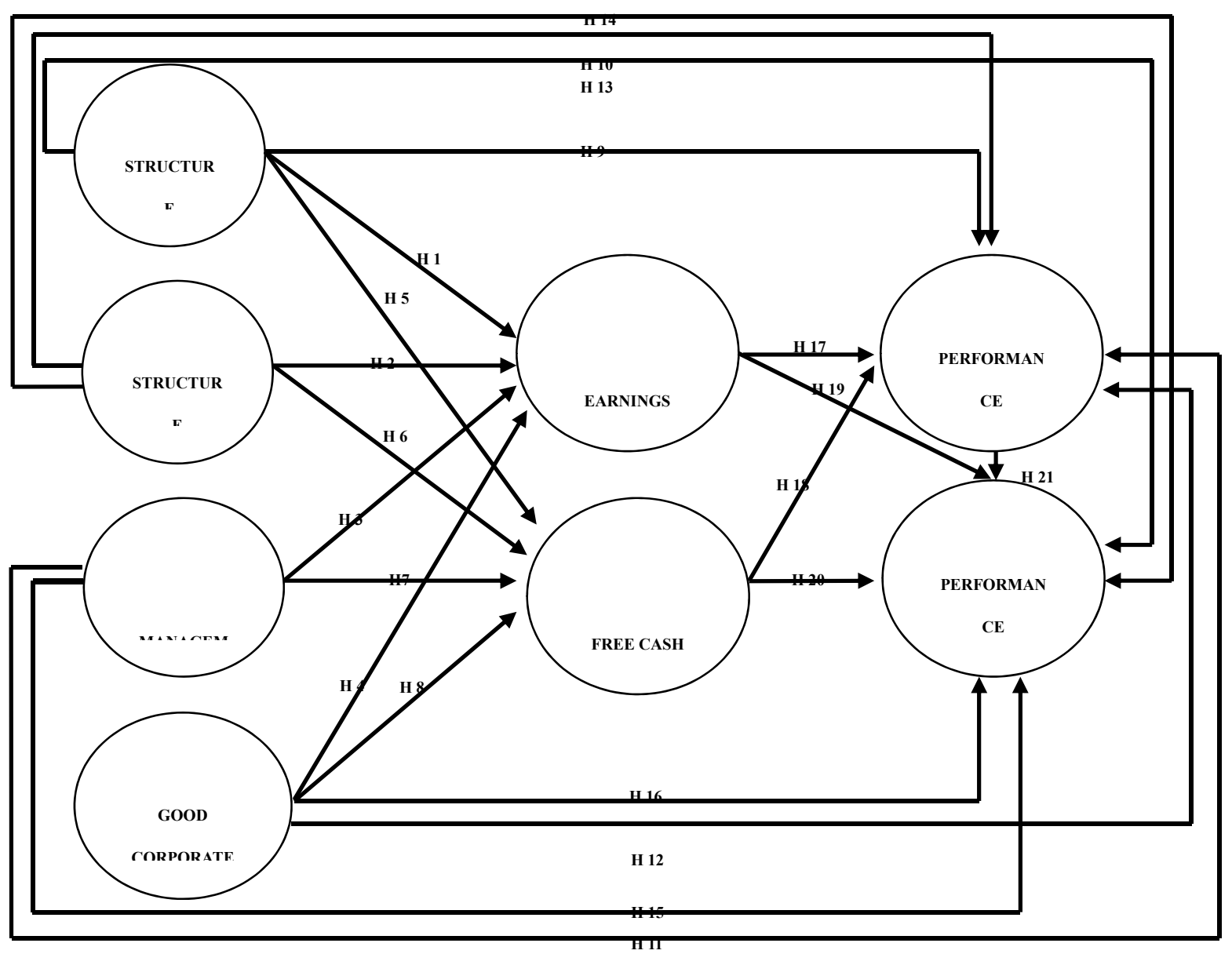

Figure 1. Conceptual framework

\section{Research Hypothesis}

Based on the description above, the hypothesis in this study are:

H1: Assets structure significantly influence on Earnings The Banking Companies Listed in Indonesia Stock Exchange.

H2: Capital Structure significantly influence on Earnings The Banking Companies Listed in Indonesia Stock Exchange. 
H3: Risk Management significantly influence on Earnings The Banking Companies Listed in Indonesia Stock Exchange.

H4: Good Corporate Governance significantly influence on Earnings The Banking Companies Listed in Indonesia Stock Exchange.

H5: Asset Structure significantly influence on Free Cash Flow The Banking Companies Listed in Indonesia Stock Exchange.

H6: Capital Structure significantly influence on Free Cash Flow The Banking Companies Listed in Indonesia Stock Exchange.

H7: Risk Management significantly influence on Free Cash Flow The Banking Companies Listed in Indonesia Stock Exchange.

H8: Good Corporate Governance significantly influence on Free Cash Flow The Banking Companies Listed in Indonesia Stock Exchange.

H9: Structure Assets significantly influence on Financial Performance The Banking Companies Listed in Indonesia Stock Exchange.

H10: Capital Structure significantly influence on Financial Performance The Banking Companies Listed in Indonesia Stock Exchange.

H11: Risk Management significantly influence on Financial Performance The Banking Companies Listed in Indonesia Stock Exchange.

H12: Good Corporate Governance significantly influence on Financial Performance The Banking Companies Listed in Indonesia Stock Exchange.

H13: Assets structure significantly influence on Value of the Firm The Banking Companies Listed in Indonesia Stock Exchange.

H14: Capital Structure significantly influence on Value of the Firm Banking Companies Listed in Indonesia Stock Exchange.

H15: Risk Management significantly influence on Value of the Firm Banking Companies Listed in Indonesia Stock Exchange.

H16: Good Corporate Governance significantly influence on Value of the Firm Banking Companies Listed in Indonesia Stock Exchange.

H17:Earnings significantly influence on Financial Performance The Banking Companies Listed in Indonesia Stock Exchange.

H18: Free Cash Flow significantly influence on Financial Performance The Banking Companies Listed in Indonesia Stock Exchange.

H19: Earnings significantly influence on Value of the Firm The Banking Companies Listed in Indonesia Stock Exchange.

H20: Free Cash Flow significantly influence on Value of the Firm Banking Companies Listed in Indonesia Stock Exchange.

H21: Financial Performance significantly influence on Value of the Firm The Banking Companies Listed in Indonesia Stock Exchange.

\subsection{Research Methodology}

This study was designed as a research explanation to explain the subject of Influence Asset Structure, Capital Structure, Risk Management and Good Corporate Governance on Financial Performance and Value of the firm Through Earnings and Free Cash Flow as an intervening variable The Banking Companies Listed in Indonesia Stock Exchange Period 2012-2015.

Data required in the secondary data. Research data is needed in this study is data from the Indonesia Stock Exchange that contains the company's performance and financial ratios, the annual report containing the annual report of the bank, as well as data from Bank Indonesia.

The population in this study is a banking company listed on the Indonesia Stock Exchange. The number of banking companies listed on the Indonesian stock exchange until January 2016, as many as 42 banks. Purposive sampling method is used in studies that more priority than research purposes in determining the nature of the 
sample population (Bungin, 2013). Purposive sampling in this study using certain basic considerations, namely:

1. The company is banking companies listed in Indonesia Stock Exchange.

2. Publish annual financial statements as of 31 December and the observation data from 2012 to 2015 consistently and regularly.

3. The financial statements issued by the Banking Companies audited.

4. Companies whose shares are actively traded on the observation period 2012-2015.

5. Companies that do not have negative earnings.

6. Companies that divide dividends for 4 consecutive years.

Based on the above sampling tenik Company acquired 10 banks listed on the Indonesia Stock Exchange.

Operational definitions and variables used in this research are as follows:

\section{Asset Structure (XI)}

The asset structure is all resources and assets owned by the company to be used in its operations which is expected to provide benefits in the future. The calculation of the asset structure is measured by the following indicators:
a. Ratio of Current Assets to Total Assets
b. Ratio of Fixed Assets to Total Assets
c. Other Assets Ratio to Total Assets
2. Capital Structure (X2)

The capital structure is the ratio of total debt to total assets or total debt to capital reflects the financing through debt either current debt or long term debt to total assets or capital.

Calculation of capital structure is measured by the following indicators:
a. Debt to Asset Ratio (DAR)
b. Debt to Equity Ratio (DER)
c. Capital Adequacy Ratio (CAR)
3. Risk Management (X3)

Risk management is a system of monitoring and risk management as well as the protection of property, property rights and profit entity or individual on the possibility of losses due to the existence of a risk management. Calculation measured by the following indicators:
a. the Value of Credit Risk
b. Loan to Deposit Ratio
c. Non Performing Loan (NPL)
d. the Value of Market Risk
e. the Value of Liquidity Risk

\section{Good Corporate Governance (X4)}

Good corporate governance or corporate governance is a process that is applied in running the company that governs the relationship between shareholders, manager of the company, the creditors, governments, employees and holders of other internal and external interests. Banks should make an assessment (self-assessment) at regular intervals at least includes 11 (eleven) GCG implementation assessment factor.

\section{Earnings (Z1)}

Earnings is the ratio of net income (after taxes) with capital or profit (before taxes) by total assets owned company at a certain period. Measurements can be made for some period of operation in order to make visible the development of the company within a certain timeframe, either decrease or increase, as well as seeking the cause of these changes.

Calculation of earnings measured by the following indicators:
a. Return on Assets (ROA)
b. Return on Equity (ROE) 


\section{c. Net Interest Margin (NIM)}

\section{Free Cash Flow / FCF (Z2)}

Free cash flow is the residual cash flow calculation produced by a company at the end of a financial period after expenditures for working capital. Ratings are based on the company's cash flow can be divided into two ways:
a. Free Cash Flow to Firm (FCFF)
b. Free Cash Flow to Equity (FCFE)

\section{Financial Performance (Y1)}

Financial performance is the achievement of work that has been achieved by the company in a certain period and embodied in the company's financial statements concerned. The financial performance variable will be measured by several indicators. The indicators used in this research are:
a. Liquidity ratio
b. Activity ratio
c. Profit growth
8. Value of the Firm (Y2)

The company's value is the actual value per share to be accepted if the company's assets are sold according to the stock price. The value of the company can deliver prosperity to the fullest shareholders if the company's stock price to rise. High enterprise value will be followed by a high prosperity shareholders. Enterprise value calculations using the following indicators:
a. Price Earning Ratio
b. Price to Book Value
c. Dividend Payout Ratio (DPR)

The method of analysis used in this research is to use Partials Least Square (PLS).

\section{Research Result}

The test results of variables and indicators using PLS as shown below:

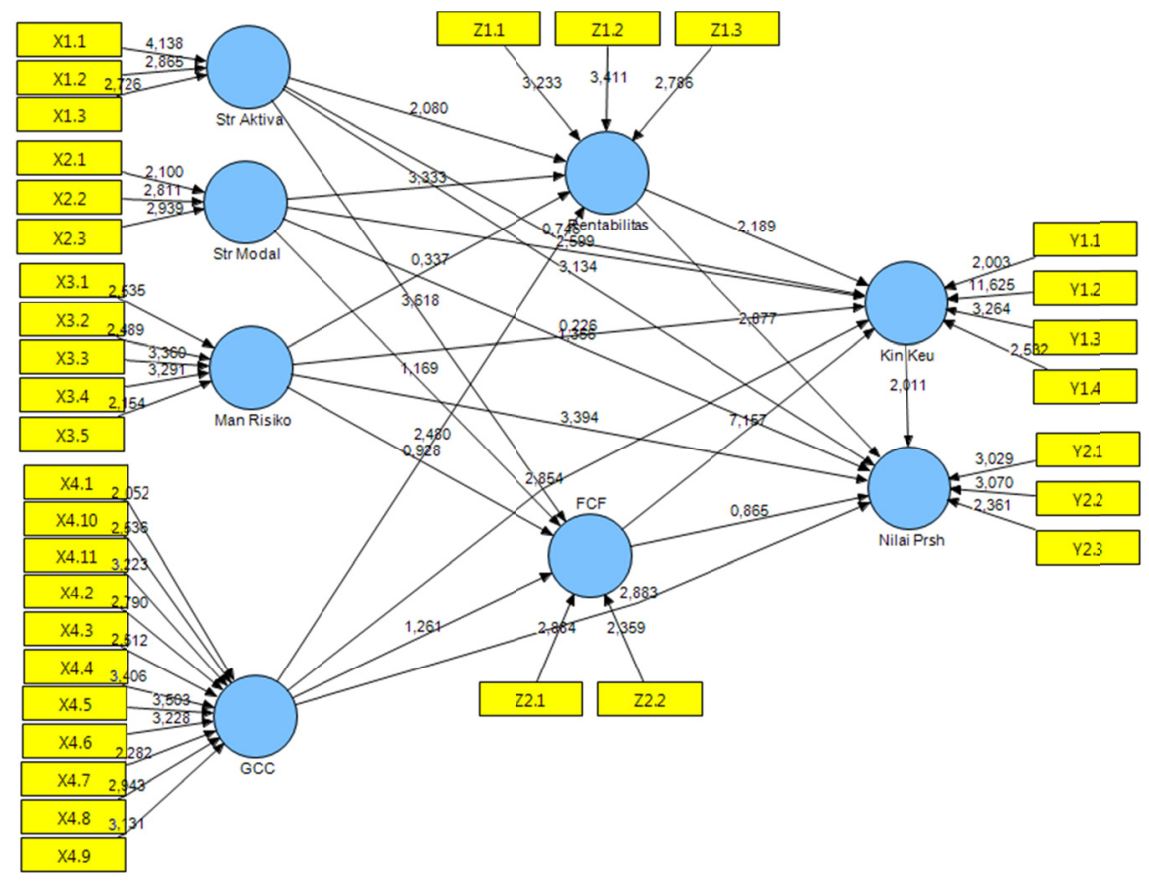

Figure 2. Structural equation model 


\subsection{Hypothesis Testing}

Test the hypothesis can be seen from the t-statistic. To test the hypothesis using the t-statistic used is 1.96 . So the hypothesis criteria were considered significant if the t-statistic $>1.96$ (Ghozali, 2014).

Table 2. Results of hypothesis testing

\begin{tabular}{|c|c|c|c|c|}
\hline Hypothesis & Variables & $\begin{array}{l}\text { Coefficient } \\
\text { Line }\end{array}$ & $\begin{array}{l}T \quad \text { Statistics } \\
(\mid \text { O/Sterr } \mid)\end{array}$ & Information \\
\hline 1 & Str Assets -> Earnings & 0.010771 & 2.079706 & significant \\
\hline 2 & Str Capital -> Earnings & -0.793226 & 3.332817 & significant \\
\hline 3 & Risk Man -> Earnings & 0.100776 & 0.336835 & not significant \\
\hline 4 & GCG -> Profitability & 0.118453 & 2.479617 & significant \\
\hline 5 & Str Assets -> FCF & 0.365618 & 3.618432 & significant \\
\hline 6 & Str Capital -> FCF & 0.334543 & 1.168941 & not significant \\
\hline 7 & Man Risk -> FCF & -0.182478 & 0.9285 & not significant \\
\hline 8 & GCG $->$ FCF & 0.378902 & 1.261109 & not significant \\
\hline 9 & Str Assets -> financial performance & -0.105329 & 0.74566 & not significant \\
\hline 10 & Str Capital -> financial performance & -0.129956 & 2.599062 & significant \\
\hline 11 & Man Risk -> financial performance & 0.022967 & 0.226404 & not significant \\
\hline 12 & GCG -> financial performance & 0.115652 & 2.853626 & significant \\
\hline 13 & Str Assets -> Company Values & 0.275092 & 3.133872 & significant \\
\hline 14 & Str Capital -> Company Values & 0.441904 & 1.35607 & not significant \\
\hline 15 & Man Risk -> Company Values & -0.768101 & 3.393802 & significant \\
\hline 16 & GCG -> Company Values & 0.158219 & 2.883235 & significant \\
\hline 17 & Earnings -> financial performance & 0.03073 & 2.18897 & significant \\
\hline 18 & FCF $->$ financial performance & 0.788453 & 7.157297 & significant \\
\hline 19 & Earnings -> Company Values & 0.396452 & 2.876807 & significant \\
\hline 20 & FCF -> Company Values & 0.360272 & 0.864579 & not significant \\
\hline 21 & $\begin{array}{l}\text { financial performance -> Company } \\
\text { Values }\end{array}$ & 0.002129 & 2.010632 & significant \\
\hline
\end{tabular}

Source: processed data (2017).

\section{Discussion}

\subsection{Assets Structure To Earnings}

Asset structure influence positive and significantly to earnings. Research from Titman and Wessels (1988) in Kesuma (2009), asset structure is the wealth or economic resources owned by the company which is expected to provide benefits in the future consisting of fixed assets, intangible assets, current assets and non-current assets. As well as the theory of Fama and French (1978), in the short term the company aims to obtain the maximum profit by using existing resources, while in the long term the company's goal is to optimize the value of the company.

\subsection{Capital Structure to Earnings}

Capital structure influence negative and significantly to earnings. Research from Brigham and Houston (2010) explains that a company must analyze multiple factors and establish targeted capital structure. However, these targets can actually be changed at any time, therefore the management should have an idea about the target-specific capital structure at any time, which is adapted to the conditions and needs of the company. The increase in bank capital from year to year which is expected to revise the confidence of investors towards increasing company. Capital demonstrate the ability of banks are getting better at managing their capital to earn profit. 


\subsection{Risk Management to Earnings}

Risk management influence positive and no significantly earnings. These research not support the theory Pandia (2012), the Bank shall apply a risk effectively. Risk management is a set of procedures and methodologies used to identify, measure, monitor and control risks arising from banks. Risk Management business activities is one important element in conducting banking business for the growing world of banking as well as the increasing complexity of these banks. These activity resulted in an increased level of risk faced by banks.

\subsection{Good Corporate Governance to Earnings}

Good Corporate Governance influence positive and significantly to earnings. These research positive and significant to support the theory of Brown and Caylor (2004), if the implementation of good corporate governance to be effective and efficient, then the whole process of the activity of the company will run well, so things related with both its corporate performance financial and non financial performance will also improve.

\subsection{Asset Structure to Free Cash Flow}

Asset structure influence positive and significantly on Free Cash Flow. This study supports the theory Titman and Wessels (1988) in Kesuma (2009) the structure of assets is the wealth or economic resources owned by the company which is expected to provide benefits in the future that consists of fixed assets, intangible assets, current assets, and non-current assets. As well as the theory of Brigham and Houston (2010) defines free cash flow as cash flow available for distribution to all investors after the companies to invest in fixed assets, new products and working capital required to maintain the continuity of the company's operations.

\subsection{Capital Structure to Free Cash Flow}

Capital structure influence positive and no significantly on free cash flow. Free as cash that can be distributed to creditors or shareholders who are not required for working capital or investment in fixed assets for the majority of free cash flow to repay the debt, so there is no free cash flow within the company that can be used by management to take action in the interests of management are detrimental to shareholders. If enough cash flow in the company with ineffective supervision of shareholders will create management measures for using the cash flow for the sake of their own interests.

\subsection{Risk Management to Free Cash Flow}

Risk management influence negative and no significantly on free cash flow. In managing the company's risk management, management must also consider the company's free cash flow. Because it can create conflicts of interest between management and shareholders. So in managing risk management and the use of free cash flow funds should provide benefits in the future and provide benefits for both companies and investors, if there was an error in managing the risk management and free cash flow will impact on the value of the company.

\subsection{Good Corporate Governance to Free Cash Flow}

Good Corporate Governance influence positive and no significantly on free cash flow. It means that good corporate governance has a positive effect and does not contribute any real effect on determining the rise and fall of free cash flow.

\subsection{Asset Structure to Financial Performance}

Asset structure influence negative and no significantly financial performance. This means that the structure of assets have a negative impact not contribute any real effect on determining the rise and fall of financial performance. Structure assets of a company will appear in the next left of the standard of balance sheet. It's important to determine how much to company allocation for each asset and other forms of assets that must owned. Because it concerns how much funding is needed directly related to the company's long-term goals.

\subsection{Capital Structure to Financial Performance}

Capital structure influence negative and significantly to financial performance. Research from Siahaan, Suhadak, Handayani and Solimun (2014), the capital structure has a negative and significant impact on financial performance. Capital structure or the high cost of debt will lead to companies having difficulty in the performance of the company.

\subsection{Risk Management to Financial Performance}

Risk management influence positive and no significantly on financial performance. This means that risk management has a positive effect and does not contribute any real effect on determining the rise and fall of financial performance. 


\subsection{Good Corporate Governance to Financial Performance}

Good Corporate Governance influence positive and significantly on financial performance. The results support the results of research and Caylor Brown (2004), which shows that good corporate governance is positive and significant impact on the performance of the company.

\subsection{Asset Structure to Value of the Firm}

Asset structure influence positive and significantly on value of the firm. These research support the theory of Fama and French (1978), In the short term the company aims to obtain the maximum profit by using existing resources, while in the long term the company's goal is to optimize the value of the company.

\subsection{Capital Structure to Value of the Firm}

Capital structure influence positive and no significantly on value of the firm. Component generally consists of core capital and complement. Capital must be managed well, because most of the banks' capital comes from the outer banks. Regulation also requires banks to maintain adequate capital and good capital management to maintain the confidence of creditors and the company's value in the eyes of shareholders and potential investors.

\subsection{Risk Management to Value of the Firm}

Risk management influence negative and significantly on value of the firm. Risk can cause a decrease in the stock price so that it will have an effect on shareholder value and the expected rate, and vice versa.

\subsection{Good Corporate Governance to Value of the Firm}

Good Corporate Governance influence positive and significantly on value of the firm. These research supports the theory of Brigham and Houston (2010), the important role of good corporate governance implementation can be seen on the side of one of the important objectives in establishing a company that in addition to improving the welfare of its owner or shareholder, also to maximize shareholder value through increasing the company's value.

\subsection{Earnings to Financial Performance}

Earnings influence positive and significantly on financial performance. This means that the earnings has a positive and significant impact on the financial performance. Banking companies are able to produce earnings that are likely to have a better bank performance.

\subsection{Free Cash Flow to Financial Performance}

Free cash flow influence positive and significantly on financial performance. This study supports the theory of Jensen (1986), if a company has excess free cash flow, then the company is likely to have a better performance than a company that has a lower free cash flow.

\subsection{Earnings to Corporate Values}

Earnings influence positive and significantly on value of the firm. Earnings reflects the company's ability to generate high profits for stakeholders. The greater the company's ability to pay dividends, and this has resulted in increased value of the company.

\subsection{Free Cash Flow to Value of the Firm}

Free cash flow influence positive and no significantly on value of the firm. This means that free cash flow has an impact and do not contribute any real effect on determining the ups and downs of the value of the firm. These research not in line with previous studies because of its different object. According Jensen (1986) states that companies with free cash flow will be better distributed in the form of dividends to shareholders. It is intended to avoid the unfavorable investment or simply for personal consumption.

\subsection{Financial Performance to Value of the Firm}

Financial performance influence positive and significantly on value of the firm. These research support the theory of Jensen and Meckling (1976), the company would have to be able to improve its performance in advance, so that the shareholders appoint a manager to manage company. Separation of control in the company can bring up the agency relationship, where the manager as agent and the shareholders as shares constituting principal. Principal delegate business decision-making to the manager who is a representative or agent from stakeholders. Manager must make decisions that aim to meet the best interests of the principal, one of which improve performance corporate finance.

\section{Conclusion}

Based on the analysis and hypothesis testing research that has been done before, so in this study can be drawn 
conclusion as follows:

1. asset structure influence positive and significantly to earnings,

2. capital structure influence negative and significantly to earnings,

3. risk management influence positive and no significantly to earnings,

4. Good Corporate Governance influence positive and significantly to earnings,

5. asset structure influence positive and significantly to free cash flow,

6. capital structure influence positive and no significantly to free cash flow,

7. risk management influence negative and no significantly to free cash flow,

8. Good Corporate Governance influence positive and no significantly to free cash flow,

9. asset structure influence negative and no significantly to financial performance,

10. capital structure influence negative and significantly to financial performance,

11. risk management influence positive and no significantly to financial performance,

12. Good Corporate Governance influence positive and significantly to financial performance,

13. asset structure influence positive and significantly to value of the firm,

14. capital structure influence positive and no significantly to value of the firm,

15. risk management influence negative and significantly to value of the firm,

16. Good Corporate Governance influence positive and significantly to value of the firm,

17. earnings influence positive and significantly to financial performance,

18. free cash flow influence positive and significantly to financial performance,

19. earnings influence positive and significantly to value of the firm,

20. free cash flow influence positive and no significantly to value of the firm and

21. financial performance influence positive and significantly to value of the firm.

\section{Suggestion}

Based on the analysis and testing conducted research and discussion, The suggestions for further research are as follows:

1. The company should further safeguard banking risk management primarily lending stability to keep growing without ignoring the precautionary principle that has been applied to any banking company.

2. Subsequent research directed linkages with other variables outside the research variables, such as earnings management and corporate social responsibility.

3. Subsequent studies using the object of the overall banking companies listed in Indonesia Stock Exchange.

4. Researchers further expected to add further illustrate the study period so that a subsequent condition and gets better results.

\section{References}

Besley, S., \& Eugene, F. B. (2008). Essential of Managerial Finance (14th ed.). New Jersey: Prentice Hall Pearson.

Brigham, E. F., \& Gapenski, L. C. (2006). Intermediate Financial Management (7th ed.). Sea Harbor Drive: The Dryden Press.

Brigham, E. F., \& Joel, F. H. (2010). Basics of Financial Management: Essentials of Financial Management. Jakarta: Four Salemba

Brown, L., \& Caylor, J. (2004). The Corporate Governance and Firm Performance, Boston Accounting Research Colloquium. December 15.

Bungin, B. (2013). Quantitative Research Methodology: Communication, Economics, and Public Policy And Other Social Sciences (2nd ed.). Cetakanke-7, Jakarta: Kencana Prenada Media Group.

Fahmi, I. (2014). Financial Statement Analysis. Bandung: Alfabeta.

Fama, E. F. (1978). The Effect of a Firm's Investment and Financing Decision on the Welfare of its Holders. 
American Economic Security, 68(3), 272-284.

Fama, E. F., \& French, K. R. (1978). Taxes, Financing Decisions, and Firm value. The Journal of Finance, 53(3), 819-843.

Ghozali, P. (2014). Structural Equation Modeling: Alternative Methods with Partial Least Square (PLS) (4th ed.). Semarang: Diponegoro University

Husnan, S. (2005). Fundamentals of Securities Portfolio Theory and Analysis (5th ed.). Yogyakarta: BPFE.

Husnan, S., \& Enny, P. (2004). Fundamentals of Financial Management Edition 3. Yogyakarta: UPP AMP YKPN.

IICG. (2001). The Corporate Governance: Corporate Governance (3rd ed.). Jakarta.

Indonesian Accountants Association (IAI). (2007). The Financial Accounting Standards. Jakarta: Four Salemba.

Jensen, M. C. (1986). Agency Costs of Free Cash Flow, Corporate Finance, and Takeovers. American Economic Review, 76(2), 323-329.

Jensen, M. C. (2001). Volume Maximation, Stakeholder Theory, and the Corporate Objective Function.Journal of Applied Corporate Finance.

Jensen, M., \& Meckling. W. H. (1976). The Theory of the Firm: Managerial Behavior, Agency Cost, Sructure Ownership. Journal of Financial Economic, 3(4), 305-360.

Kesuma, A. (2009). Analysis of Factors Affecting Capital Structure and Effect on Stock Price of Real Estate Companies That Go Public in Indonesia Stock Exchange and Enterprise. Management Journal, 11(1), $38-45$.

Kieso, D. E., Weygandt, J. J., \& Warfield, T. D. (2007). Intermediate Accounting (12th ed.). Asia: John Wiley \& Sons (Asia) Pte Ltd.

Malik, S. (2012). Relationship between Corporate Governance Score and Stock Prices: Evidence from KSE 30 Index Companies. International Journal of Business and Social Science, 4(3), 239-249.

Munawir, S. (2007). Financial Statement Analysis (4th ed.). Molds Fourteenth, Yogyakarta: Liberty.

Pandia, F. (2012). Funds Management and Health Bank. Jakarta: Rineka Reserved.

Riyanto, B. (2008). The Company Spending Basics (4th ed.). Molds Eighth, Yogyakarta: BPFE.

Sartono, A. (2009). The Financial Management Theory and Applications (4th ed.). Yogyakarta: BPFE.

Siahaan, U. M., Suhadak, S. H., \& Solimun, R. (2014). The Influence of Company Size towards Liquidity and Capital Structure, Corporate Performance and Firm Value, for the Large and Small Group Companies. European Journal of Business and Management, 18.

Subramanyam, K. R., \& John J. W. (2009). Financial Statement Analysis (10th ed.). Singapore: The McGraw-Hill Companies.

Syamsuddin, L. (2007). Corporate Financial Management: Concepts Application in: Planning, Monitoring, and Decision Making. Jakarta: PT. King Grafindo Persada.

Taswan. (2010). Banking Management (concepts, techniques, and applications) Edition II, Yogyakarta: UPP STIM YKPN.

\section{Copyrights}

Copyright for this article is retained by the author(s), with first publication rights granted to the journal.

This is an open-access article distributed under the terms and conditions of the Creative Commons Attribution license (http://creativecommons.org/licenses/by/4.0/). 